\title{
An effect of mammary gland infection caused by Streptococcus uberis on composition and physicochemical changes of cows' milk
}

\author{
E. Pecka-Kiełb1, M. Vasil ${ }^{2}$, A. Zachwieja ${ }^{3}$, W. Zawadzki' ${ }^{1}$, \\ J. Elečko' ${ }^{2}$ F. Zigo ${ }^{2}$, J. Illek ${ }^{4}$, Z. Farkašová ${ }^{2}$
}

${ }^{1}$ Wroclaw University of Environmental and Life Sciences, Department of Biostructure and Animal Physiology, Norwida 31, 50-375 Wroclaw, Poland

${ }^{2}$ Department of Animal Breeding, University of Veterinary Medicine and Pharmacy, Komenskeho 73, Kosice 041 81, Slovak Republic

${ }^{3}$ Wroclaw University of Environmental and Life Sciences, Department of Cattle Breeding and Milk Production, Chełmońskiego 38c, 51-630 Wrocław, Poland

${ }^{4}$ Clinical Laboratory for Large Animals, Faculty of Veterinary Medicine, University of Veterinary and Pharmaceutical Sciences, Brno, Czech Republic

\begin{abstract}
An effect of mammary gland infection caused by Streptococcus uberis on the changes in cows' milk composition and its physicochemical properties was examined. The study was conducted in the herd of Slovak Pied breed cattle (with a share of HF blood), in $2^{\text {nd }}$ and $3^{\text {rd }}$ lactation, after $4^{\text {th }}$ month of milking. Milk samples were collected from a quarter milking. The samples were subjected to microbiological analysis, basic milk composition, total bacteria count, somatic cell count and physicochemical properties were examined. Also analyses of protein fractions share and fatty acids profile were conducted. An effect of bacterial infection of the mammary gland bring an increase $(P<0.01)$ in somatic cell count was observed in this study. Milk samples contaminated with S. uberis were characterized by higher $(P<0.05)$ total bacteria count and total protein compared to milk samples collected from non-infected mammary gland. The level of $\kappa$-casein was significantly $(P<0.05)$ decreased in cows with subclinical mastitis caused by $S$. uberis. Significant $(P<0.05)$ reduction in the share of C13:0 acid, and an increased level of C18:0, C18:1n7t and CLA were observed in milk contaminated with $S$. uberis compared to healthy cows' milk.

It should be concluded that $S$. uberis causes the increase in total bacteria count, SCC and the decrease in $\kappa$-casein level, which significantly affects deterioration of technological quality of cows' milk.
\end{abstract}

Key words: cows, milk, Streptococcus uberis, physicochemical properties

Correspondence to: E. Pecka-Kiełb, e-mail: ewa.pecka@up.wroc.pl and M. Vasil, e-mail: milan.vasil@uvlf.sk 


\section{Introduction}

The content of protein, fat, carbohydrates, the share of protein fractions including caseins, are the factors determining biological and technological milk properties. These features are determined both by genetic and environmental factors. Intensive cattle selection performed towards the yield contributed to a decrease in biological values of raw milk and deterioration of its technological parameters, mainly due to animals resistance decrease, which results in animal diseases (Barłowska et al. 2012, Pecka et al. 2013).

Mammary gland tissue inflammation (mastitis) is the most frequent disease in dairy cattle in the world, and it brings huge economic losses (Hoeben et al. 1999, Rerk-u-suke et al. 2008). Mastitis may be a result of an infection with various bacteria species, mainly Streptococcus and Staphylococcus strains (Lidiane et al. 2012). Bacterial pathogens causing udder inflammation are classified as infectious (Staphylococcus aureus, Streptococcus agalactiae and Streptococcus bovis), and environmental (Escherichia coli, Pseudomonas aeruginosa, Streptococcus uberis, Staphylococcus chromogenem, staphylococci) (Lipman et al. 1995, Albenzio et al. 2002). Among environmental bacteria, Streptococcus uberis is often observed in milk, and they are responsible for clinical and subclinical mastitis cases both in small and large ruminants (Rerk-u-suke et al 2008).

An increase in pathogenic bacteria count in milk is accompanied by an increase in somatic cell count, and also by the changes in milk physicochemical properties (Santos et al. 2004, Rerk-u-suke et al. 2008). The udder contaminated with bacteria of Streptococcus genus may cause longer time of milk proteins coagulation and higher share of whey proteins. Also the ratio of whey proteins to caseins is subject to an increase (Leitner et al. 2006). An increase in blood-milk barrier permeability during inflammation state results in an increased movement of plasma proteins and blood enzymes, which may lead to milk proteins proteolysis (Forsback et al. 2004). Many strains of bacteria are characterized by the features of psychrotrophic bacteria spoiling the food products. They ferment lactose and may cause pseudo-lactic acid fermentation which is undesirable in cheese-making industry.

The aim of this study was an evaluation of Streptococcus uberis effect of mammary gland infection on the changes in composition and physicochemical properties of cows' milk.

\section{Materials and Methods}

The study was conducted in the herd of Slovak Pied breed cattle (with share of HF blood). The animals were housed in free-stall system and the basis of cows feeding was TMR complete mixture. Their diet was formulated according to the recommendation international of the standard (NRC, 2001). Based on performance results from three subsequent months, cows in $2^{\text {nd }}$ and $3^{\text {rd }}$ lactation with SCC up to 100 thousands / $\mathrm{ml}$ ( 8 heads, 32 quarters), and above $1 \mathrm{mln} / \mathrm{ml}$ ( 8 heads, 32 quarters), after $4^{\text {th }}$ month of lactation, were selected. Cows did not show any clinical signs of mastittis. Milk samples were collected from selected animals from the quarter milking during an evening milking to sterile containers, and they were transported to the laboratory at a temperature of $4^{\circ} \mathrm{C}$. Before milk collection, the udder was disinfected with $70 \%$ ethanol. Examined milk features were analyzed depending on the presence of Streptococcus uberis.

\section{Microbiological examinations}

The obtained samples were subjected to microbiological examinations in order to determine the level of bacterial infection, and to distinguish the samples contaminated with Streptococcus uberis, as well as non-contaminated samples, according to the following methodology: All isolates were characterized by classic microbiological methods, by primary cultivation on $5 \%$ blood agar and consistent cultivation on specific cultivation media. The streptococcal species, which were isolated from clinical cases of cows mastitis, were identified by two different identifying methods: on the basis of biochemical enzymatic properties of bacteria by STREPTOtest 24, with the identifying programme TNW 7.0 (Erba-Lachema, Brno, Czech Republic) with precision of detection over $90.0 \%$, and on the basis of determination of proteins spectrum by Maldi-Biotyper (Bruker, USA) determining of Maldi score values in range of 2.300-3.000 making species identification highly probable ( Smole et at. 2002). For the control of identification methods Streptococcus uberis strain CCM 4617 has been used (Czech strain collection of micro-organisms in Brno, Czech Republic).

\section{Analysis of milk physicochemical properties}

The content of fat, total protein, lactose and dry matter was determined in each samples using Infrared Milk Analyzer 150 (Bentley Instruments Inc.). Somatic cell count (SCC) was analyzed using Somacount 
Table 1. Basic composition, urea level and cytological quality of cows' milk.

\begin{tabular}{ccccc}
\hline Parameter & $\begin{array}{c}\text { Uninfected } \\
(\mathrm{n}=25)\end{array}$ & $\begin{array}{c}\text { Streptococcus uberis } \\
(\mathrm{n}=15)\end{array}$ & SEM & P-value \\
\hline SCC x1000* $\mathrm{ml}^{-1}$ & 199.35 & 1547.67 & 183.603 & 0.000 \\
TBC CFUx1000* $\mathrm{ml}^{-1}$ ] & 147.12 & 1087.00 & 199.105 & 0.021 \\
Fat [\%] & 4.09 & 6.07 & 0.341 & 0.004 \\
Protein [\%] & 3.31 & 4.10 & 0.154 & 0.013 \\
Dry matter [\%] & 11.91 & 14.82 & 0.477 & 0.002 \\
Lactose [\%] & 3.94 & 3.95 & 0.121 & 0.961 \\
Casein [\%] & 3.25 & 3.97 & 0.123 & 0.008 \\
Urea [m;*ml ${ }^{-1}$ ] & 353.82 & 287.95 & 14.900 & 0.031 \\
\hline
\end{tabular}

SEM - standard error of the mean

Table 2. Protein fractions share in cows' milk.

\begin{tabular}{ccccc}
\hline Parameter & $\begin{array}{c}\text { Uninfected } \\
(\mathrm{n}=25)\end{array}$ & $\begin{array}{c}\text { Streptococcus uberis } \\
(\mathrm{n}=15)\end{array}$ & SEM & P-value \\
\hline$\alpha$-kazeina [\%] & 22.48 & 31.24 & 1.521 & 0.004 \\
$\beta$-kazeina [\%] & 14.21 & 11.58 & 1.204 & 0.303 \\
א-kazeina [\%] & 15.59 & 11.50 & 0.991 & 0.045 \\
$\operatorname{IgG}_{1}[\%]$ & 11.82 & 13.54 & 0.853 & 0.335 \\
Serum albumina [\%] & 12.37 & 11.45 & 0.678 & 0.518 \\
$\alpha$-laktoalbumina [\%] & 9.03 & 8.70 & 0.491 & 0.748 \\
\hline
\end{tabular}

SEM - standard error of the mean

150 apparatus (Bentley Instruments Inc.), while total bacteria count (TBC CFU) was examined by cytometric method using Bactocount 70 analyzer (Bentley Instruments Inc.). Active acidity was determined using Level $2 \mathrm{pH}-$ meter according to the PN-A-86122 standard, and potential acidity by Soxhlet - Henkel method, the level of milk electrical resistance with Dramiński apparatus, density on DMA 35N Density Meter, casein content using Walker's method according to PN-68/A-86122,1985 standard, while urea content with CHEMSPEC apparatus.

\section{Protein fractions share}

The share of protein fractions in the obtained samples was determined using Laemmli's electrophoresis (1970) on polyacrylamide gel in the presence of sodium dodecyl sulfate (SDS) according to the methodology described by Pecka et al. (2012).

\section{Fatty acids profile}

Fat present in the examined milk was extracted using Folch's method (Christie \& William 1973). Methyl esters of fatty acids were obtained according to the method presented by Christopherson and Glass (1969), using 2M KOH solution in methanol. Fatty acids profile in obtained samples was determined using gas chromatograph Agilent Technologies 7890A with FID detector. The analyses were performed in the following conditions: capillary column HP - 88 (Agilent), length $100 \mathrm{~m}$, diameter $0.25 \mathrm{~mm}$, film thickness $0.20 \mu \mathrm{m}$; initial furnace temperature $50^{\circ} \mathrm{C}$, and temperature accretion of $3^{\circ} \mathrm{C} / \mathrm{min}$ up to $220^{\circ} \mathrm{C}$. Detector and feeder temperatures were -270 and $270^{\circ} \mathrm{C}$, respectively.

An identification of obtained fatty acids peaks was conducted by their comparison with retention times of fatty acids methyl esters standards (Sigma).

\section{Statistical analysis}

The results of the study were elaborated statistically using one-factor analysis of variance ANOVA with Statistica 10.0 software (StatSoft Poland, Krakow, Poland). Significance was declared at $p<0.05$ and $p<0.01$. Differences between means with $0.05<p<0.10$ were accepted as representing tendencies to differences.

\section{Results}

The presence of Streptococcus uberis $(\mathrm{n}=15)$ was observed in the samples obtained $(n=64)$. The highest 
Table 3. Physicochemical properties of cows' milk.

\begin{tabular}{ccccc}
\hline Parameter & $\begin{array}{c}\text { Uninfected } \\
(\mathrm{n}=25)\end{array}$ & $\begin{array}{c}\text { Streptococcus uberis } \\
(\mathrm{n}=15)\end{array}$ & SEM & P-value \\
\hline $\mathrm{pH}$ & 6.73 & 6.72 & 0.028 & 0.871 \\
Dentisty $\left[\mathrm{g} / \mathrm{cm}^{3}\right]$ & 1.036 & 1.035 & 0.001 & 0.994 \\
Resistance $[\Omega]$ & 421.15 & 421.33 & 11.263 & 0.687 \\
${ }^{\circ} \mathrm{SH}$ & 10.23 & 11.00 & 0.357 & 0.310 \\
\hline
\end{tabular}

SEM - standard error of the mean

Table 4. Fatty acids profile of cows' milk.

\begin{tabular}{|c|c|c|c|c|}
\hline Parameter & $\begin{array}{l}\text { Uninfected } \\
\quad(n=25)\end{array}$ & $\begin{array}{l}\text { Streptococcus uberis } \\
\qquad(\mathrm{n}=15)\end{array}$ & SEM & $\mathrm{P}$-value \\
\hline $\mathrm{C} 4: 0^{1}$ & 0.61 & 0.56 & 0.082 & 0.762 \\
\hline $\mathrm{C} 6: 0^{1}$ & 0.79 & 0.79 & 0.054 & 0.966 \\
\hline $\mathrm{C} 8: 0^{1}$ & 0.71 & 0.72 & 0.027 & 0.794 \\
\hline $\mathrm{C} 10: 0^{1}$ & 1.94 & 2.19 & 0.084 & 0.136 \\
\hline $\mathrm{C} 12: 0^{1}$ & 2.79 & 3.08 & 0.104 & 0.176 \\
\hline C13: $0^{1}$ & 0.10 & 0.09 & 0.003 & 0.057 \\
\hline $\mathrm{C} 14: 0^{1}$ & 10.13 & 11.05 & 0.240 & 0.284 \\
\hline C15: $0^{1}$ & 1.26 & 1.33 & 0.028 & 0.202 \\
\hline $\mathrm{C} 16: 0^{1}$ & 32.06 & 29.96 & 0.804 & 0.107 \\
\hline $\mathrm{C} 17: 0^{1}$ & 0.59 & 0.64 & 0.015 & 0.013 \\
\hline C18:0 $0^{1}$ & 7.43 & 8.79 & 0.276 & 0.025 \\
\hline $\mathrm{C} 20: 0^{1}$ & 0.16 & 0.19 & 0.008 & 0.609 \\
\hline$\Sigma$ SFA & 58.46 & 59.39 & 0.880 & 0.490 \\
\hline $\mathrm{C} 14: 1^{1}$ & 1.05 & 0.99 & 0.048 & 0.828 \\
\hline $\mathrm{C} 15: 1^{1}$ & 0.20 & 0.19 & 0.010 & 0.223 \\
\hline $\mathrm{C} 16: 1^{1}$ & 7.09 & 6.17 & 0.358 & 0.110 \\
\hline $\mathrm{C} 17: 1^{1}$ & 0.31 & 0.37 & 0.018 & 0.116 \\
\hline $\mathrm{C} 18: 1 \mathrm{n} 9 \mathrm{c}^{1}$ & 16.75 & 17.98 & 0.384 & 0.956 \\
\hline $\mathrm{C} 18: 1 \mathrm{n} 7 \mathrm{t}^{1}$ & 1.24 & 1.60 & 0.075 & 0.018 \\
\hline $\mathrm{C} 18: 1 \mathrm{t}^{1}$ & 0.86 & 0.99 & 0.082 & 0.449 \\
\hline $\mathrm{C} 18: 2 \mathrm{n} 6 \mathrm{c}^{1}$ & 1.20 & 1.23 & 0.033 & 0.669 \\
\hline $\mathrm{C} 18: 2 \mathrm{n} 6 \mathrm{t}^{1}$ & 2.38 & 2.29 & 0.173 & 0.813 \\
\hline $\mathrm{CLA}^{1}$ & 0.49 & 0.61 & 0.026 & 0.031 \\
\hline $\mathrm{C} 18: 3 \mathrm{n} 3^{1}$ & 0.47 & 0.44 & 0.025 & 0.641 \\
\hline $\mathrm{C} 20: 1^{1}$ & 0.22 & 0.23 & 0.011 & 0.836 \\
\hline $\mathrm{C} 20: 4 \mathrm{n} 6^{1}$ & 0.60 & 0.12 & 0.185 & 0.216 \\
\hline EPA & 0.06 & 0.08 & 0.005 & 0.119 \\
\hline$\Sigma$ UFA & 33.05 & 33.27 & 0.603 & 0.857 \\
\hline
\end{tabular}

SEM - standard error of the mean

${ }^{1} \mathrm{~g} / 100 \mathrm{~g}$ of total fat concentration

SFA - saturated fatty acids

UFA - unsaturated fatty acids

number of milk samples was characterized by a negative result $(n=25)$. An effect of bacterial infection of mammary gland on the increase $(p<0.01)$ in somatic cell count, fat and dry matter share was noted in the study conducted (Table 1). Milk samples contaminated with $S$. uberis were characterized by higher $(p<0.05)$ total bacteria count and total protein compared to milk samples collected from non-infected mammary gland. No statistically significant effect of bacteria presence on milk lactose level was observed. This sugar content in particular groups was on a simi- lar level of $3.9 \%$. An effect of mammary gland infection caused by $S$. uberis on an increase $(p<0.01)$ in milk caseins was noted. Reduced level $(p<0.05)$ of urea was determined in contaminated samples.

Protein fractions share in milk from healthy cows and these infected with $S$. uberis differed insignificantly (Table 2). The highest changes were observed in case of the h-casein content. This fraction share in contaminated milk was higher $(p<0.01)$ than in healthy cows' milk. Similar tendency was observed for $\mathrm{IgG}_{1}$, this fraction level in infected group increased 
by ca. $15 \%$, however the changes between the groups did no differ statistically. Higher $(P<0.05)$ level of $\kappa$-casein was observed in the milk from healthy cows. Lower levels of $\beta$-casein, $\alpha$-lactalbumin and serum albumin were noted in contaminated milk with respect to healthy cows' milk.

The $\mathrm{pH}$ value in the analyzed samples was on a similar level, i.e. 6.7, in all groups (Table 3). Also in case of such parameters like density and electrical resistance, no differences were noted between contaminated milk and milk from healthy cows. Similar lack of $S$. uberis effect was observed for ${ }^{\circ} \mathrm{SH}$ value, however a slight decrease, by about $0.77{ }^{\circ} \mathrm{SH}$, was demonstrated in non-contaminated cows' milk.

Significant $(P<0.05)$ decrease in the share of $\mathrm{C} 13: 0$ acid, and an increase in the level of C18:0, C18:1n7t and CLA were observed in milk contaminated with $S$. uberis compared to the milk from healthy cows (Table 4). The content of saturated fatty acids, except of C4:0, C6:0 and C16:0, was lower in the samples of healthy cows' milk. Insignificant effect of mammary gland infection caused by $S$. uberis on an increase in SFA and UFA levels was noted, however the differences between the groups were not confirmed statistically. The share of C14:1, C15:0, C16:0 acids was on a higher level in the presence of $S$. uberis compared to the milk from healthy cows. EPA share in healthy cows' milk samples was by about $0.02 \mathrm{~g} / 100 \mathrm{~g}$ fat lower compared to contaminated samples. An increase in the level of C18:2n6t and C18:3n3 acids was observed in milk from healthy cows. C20:4n6 share in healthy cows' milk was on a level of $0.60 \mathrm{~g} / 100 \mathrm{~g}$ fat, while in the milk from infected cows the content of this acid was lower by as much as $0.48 \mathrm{~g} / 100 \mathrm{~g}$ fat.

\section{Discussion}

Bacteria of Streptococcus genus affect udder resistance, which results in deterioration of milk and milk products quality (Merin et al. 2008). An increase in the number of pathogenic bacteria in milk is accompanied by an increased somatic cell count, which are considered as a determinant of cows' mammary gland health status (Harmon 2001, Santos et al. 2004, Lidiane et al. 2012). As a factors causing mastitis, $S$. uberis affects an increase in SCC in ruminants' milk, and similar relationship was noted in this study (Rerk-u-suke et al. 2008). The results obtained in this study also correspond well with studies of other authors who noted a positive relationship between total bacteria count and somatic cell count in milk (Laevens et al. 2010). S. uberis causes an increase in protein level, and reduced milk yield of cows at $9^{\text {th }}$ day during the clinical episodes (Lacy-Hulibert et al.
1996). Similar relationship was observed by other authors for SCC, TBC CFU as well as total protein level, but between 14th and 28th day of infection (Hoeben et al. 2009). An effect of mammary gland infection caused by $S$. uberis on an increased level of mentioned above parameters (SCC, TBC CFU, total protein) was also confirmed in this study. In sheep milk, $S$. uberis effect on protein level is slightly different, since it is subject to reduction from $3.53 \%$ to $3.37 \%$ in case of an infection (Rerk-u-suke et al 2008). In this study, the difference between total protein and casein levels in healthy cows' milk is $0.06 \%$, while in the group infected with $S$. uberis it is $0.13 \%$, which confirms the results of the research of other authors who observed an increase in total protein level with concurrent increase in serum proteins in milk of cows with mastitis (Klei et al. 1998, Leitner et al. 2006). S. uberis may affect a decrease in lactose production of about by $0.4 \mathrm{~g} / \mathrm{l}$ from 336 to $672 \mathrm{~h}$ after infection (Hoeben et al. 2009). According to other authors, milk of sheep contaminated with $S$. uberis is characterized by lower level of lactose $(3.89 \%)$ and fat $(6.11 \%)$ compared to milk from non-infected animals ( $4.32 \%$ and $7.11 \%$, respectively) (Rerk-u-suke et al. 2008). Merin et al. (2008) demonstrated in their study that infection with bacteria from Streptococcus genus causes an increase in milk lactose level, elongation in milk proteins coagulation time and lowered curd firmness.

There is a negative correlation between Streptococcus sp. (including $S$. uberis, $S$. agalactiae, $S$. dysgalactiae) and the level of fat and dry matter in milk $(-0.232$ and -0.346 , respectively), as well as positive correlation between SCC and dry matter $(\mathrm{r}=0.0002)$ and fat level $(r=0.00005)$ with no effect on lactose level (Malek dos Reis et al. 2013). Other authors observed an increase in fat level during $S$. uberis infection from 4.51 to $5.08 \mathrm{~g} / 100 \mathrm{~g}$ (Lacy-Hulibert et al. 1996).This study demonstrated an effect of mammary gland infection caused by $S$. uberis on an increase in the level of fat, dry matter and no influence on lactose level, which may prove an absence of negative effect on these milk components.

Urea level in cows' milk mainly depends on their nutrition (Godden et al. 2001, Lehloenya et al. 2008). Other authors did not observe an effect of somatic cell count, and thus mammary gland status, on milk urea level (Henao-Velásquez et al. 2014). In turn, Nielsen et al. (2005) noted an increased urea production in mammary gland in inflammation states, which is an evidence of contradictory literature data. In milk samples examined in this study, urea content was subject to a decrease caused by bacterial infection.

Milk protein substances include whey proteins and casein proteins. Milk quality is mainly determined 
by casein proteins, among which the following fractions may be distinguished: $\alpha s_{1}, \alpha s_{2}, \beta, \kappa$ and $\gamma$. From technological point of view, the most desirable is milk with an increased content of $\kappa$-casein, due to its improved technological parameters and processing usefulness (Hoeben et al. 2009, Varhimo et al. 2011, Pecka et al. 2013). An increased permeability of blood-milk barrier during the inflammation results in an increased transfer of serum proteins and blood enzymes, which may lead to an increased proteolysis of milk proteins (Forsback et al. 2010). Protolysis of caseins in milk affected by bacterial infections leads to a decrease in the share of $\alpha$ - and $\beta$ - casein (Leitner et al. 2006, Hamed et al. 2012). The results of other authors studies demonstrated a reduced share of $\alpha-, \beta-, \kappa$-casein in milk with increased SCC (Hamed et al. 2012, Zielak-Steciwko et al. 2014). The level of caseins fraction, and especially $\alpha$ and $\beta$, as well as hydrolyzed caseins, affects an increase in biofilm growth in $S$. uberis culturing. Thus, they may constitute medium for this microorganism (Varhimo et al. 2011).

A decrease in $\beta$ - and $\kappa$ - casein affected by $S$. uberis was observed in this study. SCC also influences an increase in the share of $\alpha$-lactalbumin and serum albumin (Batavani et al. 2007). S. uberis causes a growth in serum albumin from 1.01 to $1.32 \mathrm{~g} / \mathrm{l}$ (Hoeben et al. 2009). Reduction in serum albumin content in the samples contaminated with $S$. uberis was noted in the examined samples, which confirms the results of a previous study which demonstrated a decrease in serum albumin level with SCC increase (Zielak-Steciwko et al. 2014). Batavani et al. (2007) demonstrated an increase in $\mathrm{IgG}$ in subclinical udder inflammatory state from $7.43 \%$ to $26.86 \%$. These results are consistent with the results obtained in this study.

Other authors observed a tendency of $\mathrm{pH}$ growth from 6.59 to 6.69 in cows' milk with an increasing somatic cell count (in subclinical state) (Batavani et al. 2007). The results of our earlier research on milk from primiparous and multiparous cows point to similar relationship (Pecka et al. 2013). The value of $\mathrm{pH}$ should be in the range from 6.6 to 6.8 , while ${ }^{\circ} \mathrm{SH}$ value should not be lower than 5.00. Exceeding these parameters may prove poor hygienic quality of milk (Fulya 2011). Milk density is a resultant of the components contained in it, and reaches from 1.023 to $1.040 \mathrm{~g} / \mathrm{dm}$ on average (Park et al. 2007). Milk derived directly from mammary gland of healthy cow should be characterized by the electrical resistance on a level of $220 \Omega$, in subclinical states of udder inflammation this value decreases low to $185 \Omega$, while in clinical states down to $158 \Omega$ (Ilie et al. 2010). In this study, parameters like $\mathrm{pH}$, density, resistance and ${ }^{\circ} \mathrm{SH}$ were within the ranges descried bed in the literature data for healthy cows' milk.

One of the main factors affecting the level and profile of fatty acids in milk is cows' nutrition (Frelich et al. 2009, Akbaridoust et al. 2014). Metabolic disorders are observed in animal organism during inflammation states, which affects the changes in milk fatty acids profile. Mammary gland secretion derived from cows in subclinical inflammation state is characterized by a reduced share of long-chain unsaturated fatty acids and an increased content of saturated acids (Chang Ling-ling et al. 2011). Mastitis may be induced by many bacteria which needs suitable medium for their development, containing lactose, casein, fatty acids esters, etc. (Varhimo et al. 2011, Lu et. al 2012). Some staphylococcal species surveyed produced fatty acid modifying enzyme (FAME) activity, but Escherichia coli and S. uberis strains did not (Lu et. al 2012). This relationship may suggest an absence of negative effect of mammary gland infection caused by $S$. uberis on fatty acids profile in cows' milk, which was observed in this study.

Causing mammary gland inflammation, Streptococcus uberis can cause financial losses not only in the area of animal production, but affects milk quality as well.

Despite positive effect of this bacteria on an increase in the content of protein, fat, and dry matter, the changes were accompanied by an elevated level of microorganisms, SCC and reduced $\kappa$-casein level, which significantly deteriorates cheese-making quality.

\section{Acknowledgment}

This work was supported by project APVV-0679-10, project APVV-0629-07, and project VEGA-1/0449/13 (Slovak).

\section{References}

Akbaridoust G, Plozza T, Trenerry VC, Wales WJ, Auldist MJ, Dunshea FR, Ajlouni S (2014) Influence of different systems for feeding supplements to grazing dairy cows on milk fatty acid composition. J Dairy Res 81: 156-163.

Albenzio M, Taibi L, and Sevi A (2002) Prevalence and etiology of subclinical mastitis in intensively managed floks and related changes in the field and quality of ewe milk. Small Rum Res 43: 219-226.

Barłowska J, Litwińczuk Z, Brodziak A, Chabuz W (2012) Effect of the production season on nutritional value and technological suitability of milk obtained from intensive (TMR) and Traditional Feeding system of cows. JMBFS 1: $1205-1220$.

Batavani RA, Asri S, Naebzadeh H (2007) The effect of subclinical mastitis on milk composition in dairy cows. Iranian J Vet Res. 8: 205-211.

Chang L., Yang Z., Wu H., Chen Y., Shi X., Mao Y., Cen N., Liang X., Yin Z. (2011) Comparative Study on Fatty Acid Composition between Normal Milk and Subclinical Mastitis Milk of Dairy Cow. Chines J Anim Vet Sci 43: $44-47$ 
Christie W, William S (1973) Lipid analysis. Isolation, separation, identification and structural analysis of lipids. The isolation of lipids from tissues. 1st ed., Pergamon Press, Oxford pp. 39-40.

Christopherson SW, Glass RL (1969) Preparation of milk fat methyl esters by alcoholysis in an essentially nonalcoholic solution. J Dairy Sci 52: 1289-1290.

Cromwell, G I (2001) Nutrient requirements of dairy cattle. 7th revised ed., National Academy Press 2001. p 408.

Forsbäck L, Lindmark-Mansson H, Andren A, Svennersten-Sjaunja K (2010) Evaluation of quality changes in udder quarter milk from cows with low to- moderate somatic cell counts. Animal 4: 617-626.

Frelich J, Šlachta M, Hanuš O, Špička J, Samková E (2009) Fatty acid composition of cow milk fat produced on low-input mountain farms. Czech J Anim Sci 12: 532-539.

Fulya T (2011) Microbiological and Chemical Properties of Raw Milk Consumed in Burdur. J Anim Vet Adv 10: 635-641.

Godden SM, Lissemore KD, Kelton DF, Leslie KE, Walton JS, Lumsden JH (2001) Factors associated with milk urea concentrations in Ontario dairy cows. J Dairy Sci 84: 107-114.

Hamed H, Truijllo, AJ, Juan B, Guamis B, ElFeki A, Gargouri A (2012) Interrelationships between somatic cell counts, lactation stage and lactation number and their influence on plasmin activity and protein fraction distribution in dromedary (Camelus dromedaries) and cow milks. Small Rum Res 105: 300-307.

Harmon RJ (2001) Somatic cell counts: A primer. Madison to Reno. National Mastitis Council Annual Meeting Proceedings pp 3-9.

Henao-Velásquez AF, Múnera-Bedoya OD, Herrera AC, Agudelo-Trujillo JH, Cerón-Muñoz MF (2014) Lactose and milk urea nitrogen: fluctuations during lactation in Holstein cows. R Bras Zootec 43: 479-484.

Hoeben D, Burvenich C, Eppard PJ, Hard DL (1999) Effect of Recombinant Bovine Somatotropin on Milk Production and Composition of Cows with Streptococcus uberis Mastitis. J Dairy Sci 82: 1671-1683.

Ilie LI, Tudor L, Galiş AM (2010) The electrical conductivity of cattle milk and the possibility of mastitis diagnosis in Romania. Lucrări Ştiinţifice Medicinǎ Vet 2: 220-227.

Klei L, Yun J, Sapru A, Lynch J, Barbano D, Sears P, Galton D (1998) Effects of milk somatic cell count on cottage cheese yield and quality. J Dairy Sci 81: 1205-1213.

Lacy-Hulbert SJ, Woolford MW, Nicholas G, Stelwagen K (1996) Effect of Streptococcus uberis infection on milk characteristics of individual quarters. Proceedings of the New Zealand Society of Animal Production 56: 65-67.

Laemmli UK (1970) Cleavage of structural proteins during the assembly of the head of bacteriophage T4 Nature London 227: 680-685.

Laevens H, Deluyker H, Schukken YH, De Meulemeester L, Vandermeersch R, De Muelenaer E, De Kruif A (1997) Influence of Parity and Stage of Laction on the Somatic Cell Count in Bacteriologically Negative Dairy Cows. J Dairy Sci 80: 3219-3226.

Lehloenya KV, Stein DR, Allen DT, Selk GE, Jones DA, Aleman MM, Rehberger TG, Mertz KJ, Spicer LJ (2008) Effects of feeding yeast and propionibacteria to dairy cows on milk yeld and components, and reproduction. J Anim Physiol Animal Nutr 92: 190-220.

Leitner G, Krifucks O, Merin U, Lavi Y, Silanikove
$\mathrm{N}$ (2006) Interactions between bacteria type, proteolysis of casein and physico-chemical properties of bovine milk. Int Dairy J 16: 648-654.

Lidiane CS, Pereira IA, Pribul BR, Oliva MS, Coelho SM, Souza MM (2012) Antimicrobial resistance and detection of mec $\mathrm{A}$ and bla $\mathrm{Z}$ genes in coagulase-negative Staphylococcus isolated from bovine mastitis. Pesq Vet Bras 32: 692-696.

Lipman LJ, de Nijs A, Lam, TJ, Gaastra W (1995) Identification of Escherichia coli strains from cows with clinical mastitis by serotyping and DNA polymorphism patterns with REP and ERIC primers. Vet Microbiol 43: 13-19.

Lu T, Park JY, Parnell K, Fox LK, McGuire MA (2012) Characterization of fatty acid modifying enzyme activity in staphylococcal mastitis isolates and other bacteria. BMC Rese Notes 5: 323.

Malek dos Reis C B , Barreiro JR, Mestieri L, de Feltcio Porcionato M A, dos Santos MV (2013) Effect of somatic cell count and mastitis pathogens on milk composition in Gyr cows. BMC Vet Res 9: 67.

Merin U, Fleminger G, Komanovsky J, Silanikove N, Bernstein S, Leitner G (2008) Subclinical udder infection with Streptococcus dysgalactiae impairs milk coagulation properties: The emerging role of proteose peptones. Dairy Sci. Technol 88: 407-419.

Nielsen HI, Larsen T, Bjerring M, Ingvartsen KL (2005) Quarter health, milking interval, and sampling time during milking affect the concentration of milk consistents. J Dairy Sci 88: 3186-3200.

Park YW, Juárez M, Ramos M, Haenlein GF (2007) Physico-chemical characteristics of goat and sheep milk. Small Ruminant Res 68: 88-113.

Pecka E, Dobrzański Z, Zachwieja A, Szulc T, Czyż K (2012) Studies of composition and major protein level in milk and colostrum of mares. Anim Sci J 83: 162-168.

Pecka E, Zachwieja A, Tumanowicz J (2013) Technological parameters of milk depending on the cow housing system, nutrition system, age and number of somatic cells. Przem Chem 92: 1087-1091.

Rerk-u-suke S, Samngamnim1 S, Koowatananukul C, Ajariyakhajorn K (2008) Effect of Streptococcus uberis Causing Intramammary Infection on Raw Milk Compositions. Proceedings, the 15th Congress of FAVA 27-30 October, Bangkok, Thailand FAVA - OIE Joint Symposium on Emerging Diseases.

Santos JE, Cerri RL, Ballou MA, Higginbotham GE, Kirk $\mathrm{JH}$ (2004) Effect of timing of first clinical mastitis occurrence on lactational and reproductive performance of Holstein dairy cows. Anim Reprod Sci 80: 31-45.

Smole SC, King LA, Leopold PE, Arbeit RD (2002) Sample preparation of Gram-positive bacteria for identification by matrix assisted laser desorption time-of-flight. J Microbiol Meth 48: 107-115.

Varhimo E, Varmanen P, Fallarero A, Skogman M, Pyorala S, Livanainen A, Sukura A, Vuorel P, Savijoki (2011) Alpha- and $\beta$-casein components of host milk induce biofilm formation in the mastitis bacterium Streptococcus uberis. Vet Microbiol 149: 381-389.

Zielak-Steciwko A, Pecka E, Kęsek M, Kuczaj M, Szulc $\mathrm{T}$ (2014) Changes in the proportion of proteins fractions depending on lactoferrin polymorphism gene and the somatic Cells Count in the milk of Polish Holstein-Frisian and Polish Red-White cattle. Vet Med Zoot 88: 83-89. 